Maria J. Sousa $\cdot$ F. Xavier Malcata

\title{
Comparative biochemical evolution during ripening of bovine, ovine and caprine cheeses manufactured with extracts of flowers of Cynara cardunculus
}

\begin{abstract}
Changes in the main physicochemical and biochemical characteristics of bovine, ovine and caprine milk cheeses manufactured with aqueous extracts of flowers of Cynara cardunculus were studied throughout ripening (0-68 days). At the end of ripening the $\mathrm{pH}$ in the centre was (mean \pm ISD) $5.05 \pm 0.07,5.15 \pm 0.21$ and $4.91 \pm 0.07$ for bovine, ovine and caprine milk cheeses, respectively; whereas the $\mathrm{pH}$ at the top of the cheese was $5.21 \pm 0.09$, $5.44 \pm 0.12$ and $5.12 \pm 0.07$, respectively; the moisture content values of bovine, ovine and caprine milk cheeses were $37.68 \pm 2.32,40.23 \pm 4.34$ and $45.73 \pm 1.44 \%$, respectively; the $\mathrm{NaCl}$ content values were $4.00 \pm 0.43$, $4.00 \pm 0.56$ and $4.08 \pm 0.58$ (\%TS); the fat content values were $41.01 \pm 5.32,63.60 \pm 7.80$ and $45.14 \pm 9.14$ (\%TS); the protein content values were $28.96 \pm 1.84,22.89 \pm 2.37$ and $30.02 \pm 1.22$ (\%TS); the water-soluble nitrogen values were $32.91 \pm 1.76,46.44 \pm 1.86$ and $48.72 \pm 1.08$ (\%TN); the values of nitrogen soluble in trichloroacetic acid were $10.25 \pm 1.93,10.41 \pm 2.91$ and $7.25 \pm 0.84(\% \mathrm{TN})$; the values of nitrogen soluble in phosphotungstic acid were $1.50 \pm 0.18,1.87 \pm 0.65$ and $1.38 \pm 0.32$ (\%TN); finally, the free amino acid content values were $21.33 \pm 5.34$, $17.51 \pm 5.08$ and $23.93 \pm 4.80 \mathrm{mM}$ equivalents of leucine. Urea-polyacrylamide gel electrophoresis of water-insoluble fractions from cheeses indicated high degrees of proteolysis of a s1-casein in bovine cheeses and more extensive proteolysis of the $a_{\mathrm{s}}$-casein region in caprine than in ovine cheeses, but a moderate degree of proteolysis of b-casein in all types of cheese; electrophoregrams of the watersoluble fraction displayed increasing numbers of bands throughout ripening, an observation that is consistent with the increase in the ratio of water-soluble nitrogen to total nitrogen.
\end{abstract}

Key words Proteolysis - Bovine cheese - Ovine cheese $\cdot$ Caprine cheese $\cdot$ Cynara cardunculus

M. J. Sousa · F. X. Malcata (

Escola Superior de Biotecnologia, Universidade Católica Portuguesa, Rua Dr. António Bemardino de Almeida, P-4200 Porto, Portugal

\section{Introduction}

Proteolysis is regarded as the most important biochemical event during ripening of cheese $[1,2]$. Products of proteolysis range from large polypeptides, through a range of medium and small peptides down to free amino acids. The type of coagulant, microbial acidification and plasmin action are all factors which play major roles in proteolysis during cheese manufacture and ripening [2-7]. Progression of ripening can be followed by several methods including: fractionation with water, trichloroacetic acid (TCA), or phosphotungstic acid (PTA); chromatography based on size exclusion and ion exchange; and PAGE with urea added as a denaturant.

Water, TCA and PTA have been widely used for cheese fractionation $[8,9]$. The water-insoluble fraction contains caseins and high-molecular-weight products of casein breakdown, and the extract may be further analysed by urea-PAGE $[3,10]$. The soluble fraction is very heterogeneous and can be separated into several different fractions by gel filtration $[3,11]$. Water-soluble nitrogen $(\mathrm{N})$ components result chiefly from the action of the coagulant $[3,12]$. The $12 \%$ TCA-soluble $\mathbf{N}$ fraction contains small peptides (2-20 residues) [13] and amino acids, while the large and medium peptides are found in the precipitate $[8,9]$; therefore, this fraction has been used as an indicator of cheese maturation [14]. The action of starter enzymes leads primarily to the formation of small peptides and amino acids [15] and is the source of most of the $12 \%$ TCA-soluble $\mathbf{N}$. Fractionation with 5\% PTA only extracts low-molecularweight peptides ( $<600 \mathrm{Da})$.

Electrophoresis in alkaline urea-PAGE is widely used to study proteolysis in cheese during ripening $[2,16]$. Unfortunately, only the larger peptides can be visualized in gel electrophoresis, which essentially limits this technique to estimating the disappearance of caseins and their larger primary products. Despite this limitation, urea-PAGE is a powerful tool for following the hydrolysis of caseins during the early stages of cheese maturation and for comparing hydrolysis pattems in different cheeses [17]. This feature 
may be useful when milks of different species are used for cheese manufacture [18].

Aqueous extracts of flowers of Cynara cardunculus have been used as a milk coagulant since ancient times in the traditional manufacture of various Portuguese farm cheeses from raw ovine milk; however, understanding of the pathways of ripening brought about by this plant coagulant lags far behind that of most pasteurized bovine milk cheeses. Fundamental work encompassing the action of this plant rennet on ovine and caprine milks is scarce, and extrapolation from the conclusions obtained with pure bovine caseins must be done carefully. In fact, ovine and caprine milk caseins exhibit two groups of protein bands in electrophoregrams. The group with lower mobility contains b-casein and is divided into its two varieties, $b_{1}$ and $b_{2}$, which differ in their level of phosphorylation (6 versus 5) $[19,20]$. The group with higher mobility consists of three bands in ovine milks with mobilities similar to those of bovine $a_{\mathrm{s} 3-}$ and a s4-caseins [21], which have been tentatively termed ovine $\mathbf{a}_{\mathrm{s1}}$-, $\mathbf{a}_{\mathrm{s2}}$ - and $\mathbf{a}_{\mathrm{s3}}$-caseins. The caprine casein group with higher mobility ( $\mathrm{a}_{\mathrm{s}}$-caseins) comprises between three and five bands and contains a s1-casein [22]; this variability, caused by genetic polymorphism [23], is enhanced by animal and seasonal differences [24-26].

The primary objective of this work was to characterize the major physicochemical and biochemical parameters of bovine, ovine and caprine cheeses manufactured with this plant coagulant throughout the ripening period and so shed some light onto its mode of action. Increasing the fundamental knowledge of this process will certainly enhance the predictability of the behaviour exhibited by such plant rennet in new types of cheesemaking processes and permit the optimization of this behaviour in existing types of cheesemaking processes.

\section{Materials and methods}

Enzyme. Dried flowers of the wild thistle (C. cardunculus) were obtained from local shops in Serra da Estrela region (Portugal). The crude extract was prepared by grinding the stylets of the flowers for $45 \mathrm{~s}$, homogenizing them in distilled water for $15 \mathrm{~min}$, and then filtering through a fine piece of cloth.

Cheesemaking. Raw bovine, ovine and caprine milk cheeses were manufactured using the $\mathbf{C}$. cardunculus extracts as coagulant following an adaptation of the traditional technology [27]. The raw milk was heated to $28{ }^{\circ} \mathrm{C}$, salted $(3 \mathrm{~g} / \mathrm{l})$ and left to coagulate for $50 \mathrm{~min}$ by addition of $0.16 \mathrm{~g}$ of crude stylets/l. The curd was cut, stirred for $30 \mathrm{~min}$, allowed to set to promote whey drainage, placed into cylindrical moulds and lightly pressed by hand. The cheeses were salted with dry salt on the surfaces and $24 \mathrm{~h}$ later were placed at $6{ }^{\circ} \mathrm{C}$ and $92 \%$ relative humidity. After 14-20 days the cheeses were washed with warm water and salt. The cheeses $(500 \pm 100 \mathrm{~g}$ in mass, $100.0 \pm 10.0 \mathrm{~mm}$ in diameter and $50 \pm 10.0 \mathrm{~mm}$ in height) were turned upside down daily for 68 days. In total, 24 cheeses of each type (i.e. using bovine, ovine or caprine milks) were manufactured according to this procedure.

Chemical analyses. Cheeses were sampled for analysis after $0,3,7,14$, $28,42,56$ and 68 days of ripening. The total solids content (TS) was determined by oven-drying at $100{ }^{\circ} \mathrm{C}$ as described by Kosikowski [28]. Salt was assayed by the modified Volhard method using silver nitrate and potassium thiocyanate (Merck, Darmstadt, Germany), as described by Kosikowski [28]. The $\mathrm{pH}$ was measured by probing the cheese directly with a glass electrode connected to a potentiometer Microph 2001 (Crison, Barcelona, Spain). The total nitrogen (TN) content of cheese was determined by the micro-Kjeldahl procedure (IDF, 1993) adapted to micro conditions by using one-tenth of all samples and reagents in a Kjeltec system 1002 (Tecator, Höganäs, Sweden). The fat content was determined by the Van Gulik method using $40 \%$ sulphuric acid; after addition of each acid portion, the butyrometer was shaken well until all the protein was digested; a few drops of amylic acid were added to the butyrometers, which were then filled with sulphuric acid and centrifuged (Noma milk-G24, Milan, Italy), and the fat percentage was read. All determinations were made in duplicate.

Nitrogen fractions. Water-soluble nitrogen (WSN) was determined by the procedure of Kuchroo and Fox [8]. Grated cheese ( $\mathrm{x}$ g) was homogenized with $2 \mathrm{x}$ ml $\mathrm{H}_{2} \mathrm{O}$ for 5 min using a Stomacher 400 (Colworth, London, UK) and the resultant homogenate was held at $40{ }^{\circ} \mathrm{C}$ for $1 \mathrm{~h}$. The insoluble material was then separated by centrifugation at $10,000 \mathrm{~g}$ for $30 \mathrm{~min}$ in a refrigerated centrifuge (Sorval $\mathrm{RC} 5 \mathrm{C}$ Wilmington, USA) at $4^{\circ} \mathrm{C}$, and the supernatant was filtered through glass wool. Samples of water-insoluble nitrogen (WISN) and WSN were freeze-dried prior to further analysis. TCA-soluble extract was prepared by adding $y \mathrm{ml}$ of $48 \%$ TCA to $4 \mathrm{y} \mathrm{ml}$ of WSN. The mixture was allowed to stand for $30 \mathrm{~min}$ at $20{ }^{\circ} \mathrm{C}$ and filtered through Whatman no. 42 filter paper. The $\mathrm{N}$ content was determined using a sample of the filtrate. PTA-soluble extract was prepared by adding $14.0 \mathrm{ml}$ of $\mathrm{H}_{2} \mathrm{SO}_{4}$ $(3.95 \mathrm{M})$ and $6 \mathrm{ml}$ of PTA $(33.3 \%$, w/v) to $20 \mathrm{ml}$ of WSN. The mixture was allowed to stand overnight at $4{ }^{\circ} \mathrm{C}$ and subsequently filtered through Whatman no. 542 filter paper. The nitrogen contents in samples of the water-soluble, the TCA-soluble and the PTA-soluble extracts were determined by the micro-Kjeldahl procedure. The ripening extension index (represented by the ratio WSN/TN), the ripening depth index (represented by the ratio TCA-soluble N/TN [29]) and the free amino acid index (represented by the ratio PTA-soluble N/TN [30]) were all calculated. The extent of release of free amino acids was determined in duplicate using the water-soluble extract by the cadmium-ninhydrin (Cd-ninhydrin) method of Folkertsma and Fox [31]. The water-soluble extract (10-60 $\mathrm{m}$, depending on the concentration of free amino acids expected) was diluted to $1 \mathrm{ml}$ with $\mathrm{H}_{2} \mathrm{O}$ and $2 \mathrm{ml}$ of the Cd-Ninhydrin reagent was then added. The mixture was heated at $84{ }^{\circ} \mathrm{C}$ for $5 \mathrm{~min}$, cooled to room temperature and its absorbance was measured at $507 \mathrm{~nm}$ against a reagent blank containing no WSN. All determinations were made in duplicate.

Casein proteolysis. PAGE (12.5\% C, 4\% T, pH 8.9) was performed on cheeses, as well as on water-soluble and water-insoluble extracts, using a Protean II XI vertical slab-gel unit (Bio-Rad Laboratories, Watford, UK) and the stacking gel system of Andrews [32] with modifications [33]; the gels were stained with Coomassie Blue G-250 using the method of Blakesley and Boezi [34]. Quantification of intact $b$ and $a_{s^{-}}$ caseins was by densitometry using a Model CD60 densitometer (Desaga, Sarstedt-Gruppe, Germany).

\section{Results and discussion}

The mean overall values of $\mathrm{pH}$ at the top and at the centre of the cheese, moisture, $\mathrm{NaCl}$, fat, protein, WSN/TN, TCAsoluble/TN, PTA-soluble/TN and free amino acid content throughout ripening (at $0,3,7,14,28,42,56$ and 68 days) are depicted in Fig. 1. The pH at the top and at the centre of the cheeses (Fig. 1 a, b) decreased only slightly relative to that of the raw milk (result not shown), probably as a consequence of the absence of lactic acid starters. The pH decreased during whey drainage and increased slightly after 28 days of ripening at the top of the cheeses, particularly in cheeses manufactured with ovine milk. This behaviour 
Fig. 1 Average values (from a set of two replicates) of $\mathrm{pH}$ at the top (a) and in the centre (b) of the cheese, moisture content (c),

$\mathrm{NaCl}$ content (d), fat content (e), protein content (f), WSN/TN (g), TCA-soluble N/TN (h), PTAsoluble N/TN (i) and free amino acid content (j) for bovine ( $\bigcirc$ ), ovine ( $\square$ ) and caprine (D) cheeses manufactured with extracts of Cynara cardunculus throughout the ripening period. Standard errors of the means

(SEM) for bovine, ovine and caprine cheeses are as follows: $\mathrm{pH}$ at the top: $0.09,0.12$ and 0.07 pH in the centre: $0.07,0.21$ and 0.07; moisture content: $2.32,4.34$ and $1.44 \%$; $\mathrm{NaCl}$ content: 0.43 , 0.56 and 0.58 (\%TS); fat content: 5.32, 7.80 and 9.14 (\%TS); protein content: $1.84,2.37$ and 1.22 (\%TS); WSN: 1.76, 1.86 and 1.08 (\%TN); TCA-soluble N: 1.93, 2.91 and 0.84 (\%TN); PTA-soluble $\mathrm{N}$ : $0.18,0.65$ and 0.32

(\%TN); and free amino acid content: 5.34, 5.08 and $.80(\mathrm{mM}$ equivalent of leucine). (WSN Water-soluble nitrogen, TN total nitrogen, PTA phosphotungstic acid, TCA trichlonoacetic acid)
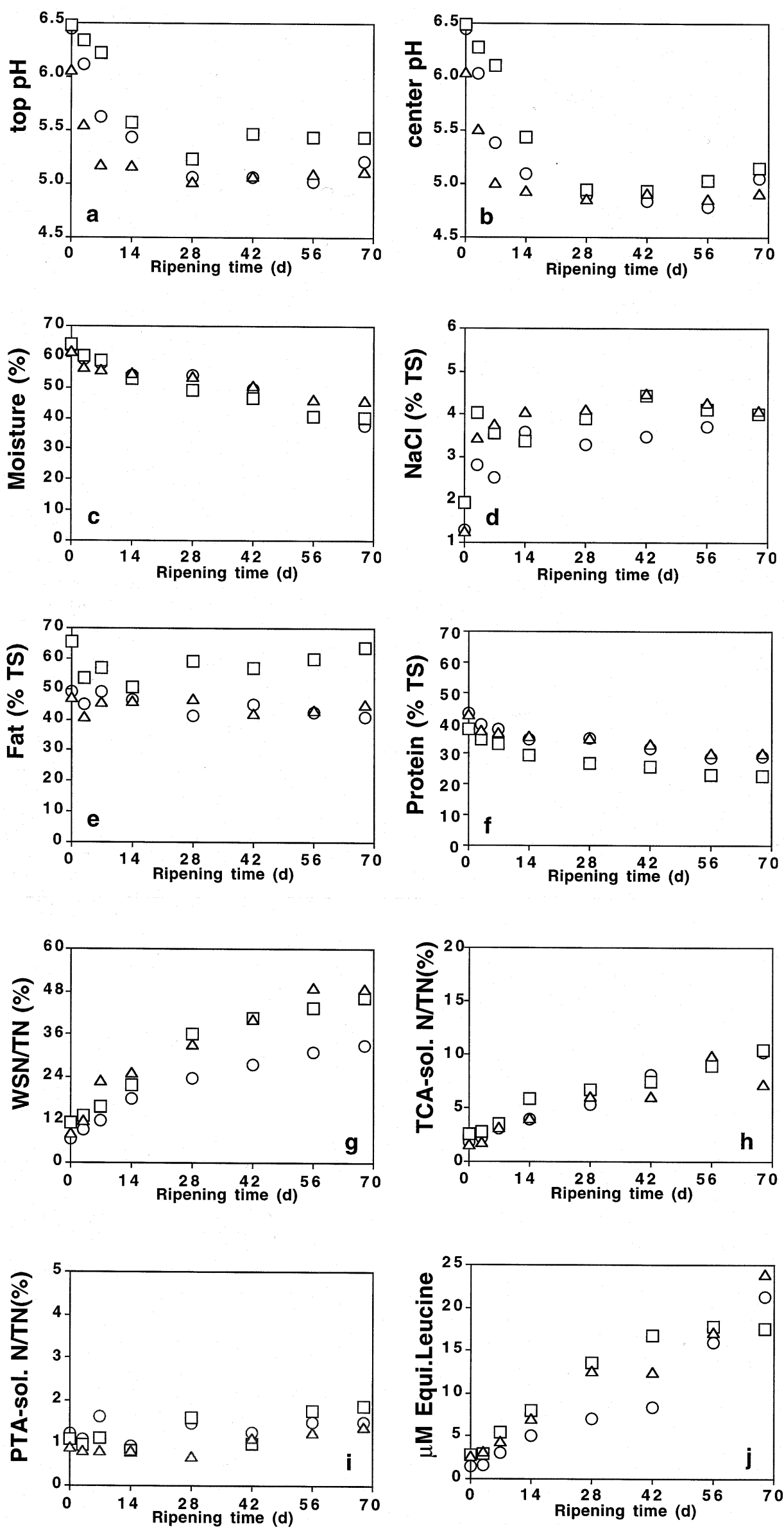
Fig. 2a (For continuation and legend see p. 102)

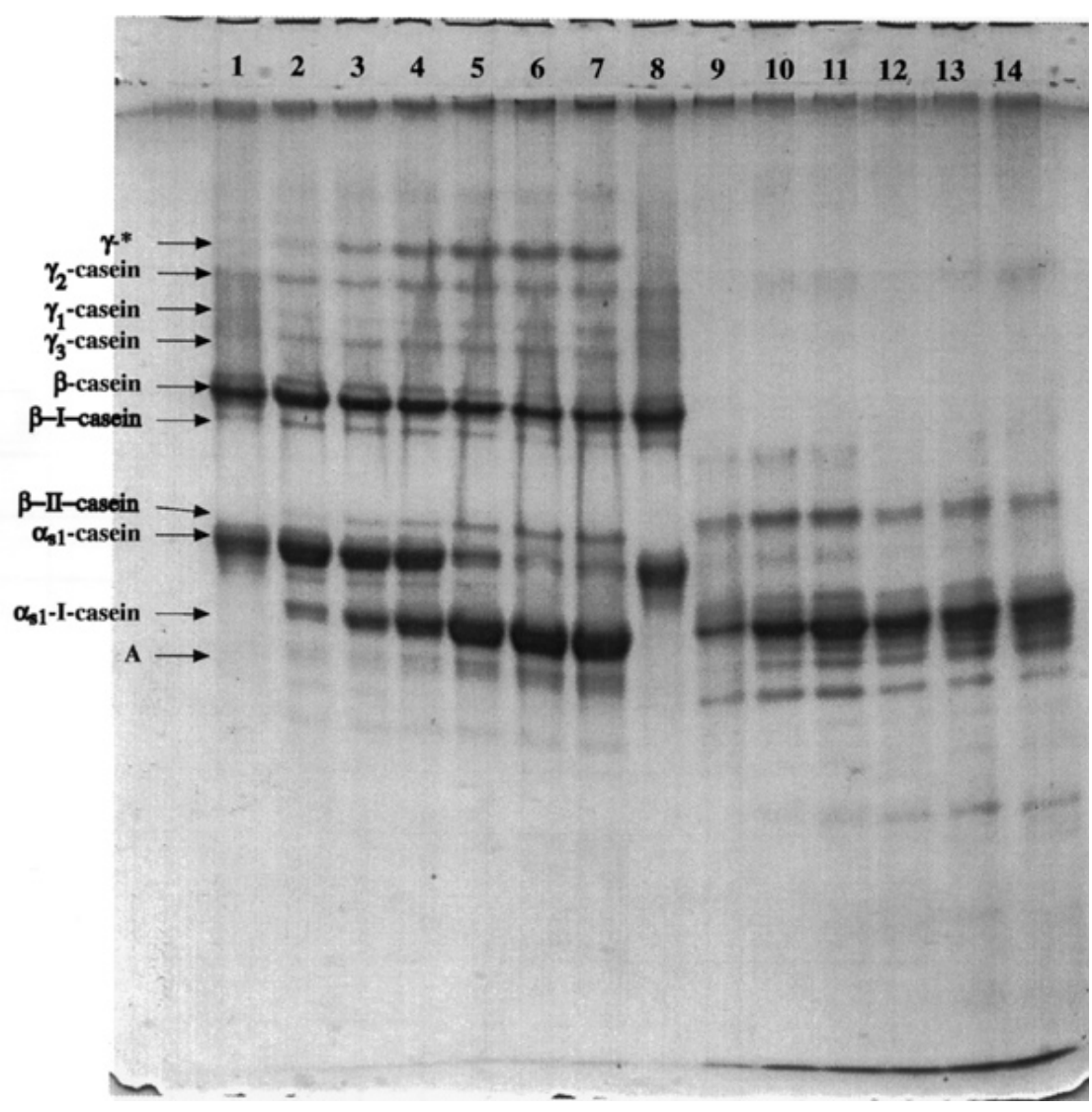

arises probably as a result of the metabolism of lactic-acidutilizing yeasts and/or ammonia production by yeasts following proteolysis $[35,36]$. Similar trends in $\mathrm{pH}$ have been reported for Serra da Estrela cheese [27], La Serena cheese [37] and Casar de Cáceres cheese [38] during ripening. The moisture contents $(\%)$ of the cheeses manufactured with bovine, ovine or caprine milks (Fig. 1 c) were similar at 0 days of ripening and decreased almost linearly with time over the ripening period. The $\mathrm{NaCl}$ content (\%TS) (Fig. $1 \mathrm{~d}$ ) of the cheeses increased during the first 3 days of ripening, which is likely to be because of $\mathrm{NaCl}$ diffusing into the cheese, and remained relatively constant throughout the remainder of the ripening period. The salt concentration is of great importance in cheese ripening due to its influence on the proteolytic activity [37], the specificity of the rennet [39] and growth and metabolism of lactic acid bacteria [40] via control of available water. Ovine milk has higher protein $(6.06 \%)$ and fat $(8.40 \%)$ contents than caprine milk $(4.70 \%$ and $3.80 \%$, respectively) and bovine milk (3.50\% and $3.55 \%$, respectively). The fat content (\%TS) (Fig. $1 \mathrm{e}$ ) of the cheeses manufactured with bovine or caprine milks were similar throughout the ripening period but lower than the fat content of the cheeses manufactured with ovine milk, while the total protein content (\%TS) (Fig. 1f) was lower for ovine milk cheeses than for cheeses manufactured with bovine or caprine milks.
The WSN/TN ratio in cheeses manufactured with bovine, ovine or caprine milk (Fig. $1 \mathrm{~g}$ ) increased throughout the ripening period; this ratio has been used by a number of researchers to follow the ageing of cheese. The WSN/TN ratio was highest for ovine milk cheese at 0 days of ripening; however, after 68 days of ripening this ratio was similar for ovine and caprine milk cheeses, thus indicating more extensive ageing compared to bovine milk cheeses. The relatively high initial value of WSN/TN might be attributed to the type of coagulant used, which is known to display considerable proteolytic activity concomitant with its clotting activity. Soluble N components are produced mainly by the action of rennet $[3,12,41]$, but starter and, to a lesser extent, milk proteinase can also contribute to the production of soluble $\mathrm{N}$ compounds in cheese [41]. The TCA-soluble N/TN ratio has been used to evaluate the action of lactic acid bacteria in the formation of soluble $\mathrm{N}$ compounds in cheese [29]; this fraction contains small peptides of between 2 and 20 amino acid residues. The value of the TCA-soluble N/TN ratio of the cheeses (Fig. $1 \mathrm{~h}$ ) increased throughout ripening, thus indicating a moderate degree of proteolysis. Rennet is generally recognized to possess the ability to produce large $\mathrm{pH}-4.6$-soluble peptides from casein but a limited capacity to break casein down further than polypeptides $[3,42]$; the action of starter bacteria or other enzymes is less important at this level of proteolysis but is primarily responsible for the production 
Fig. $2 b$ (For continuation and legend see p. 102)

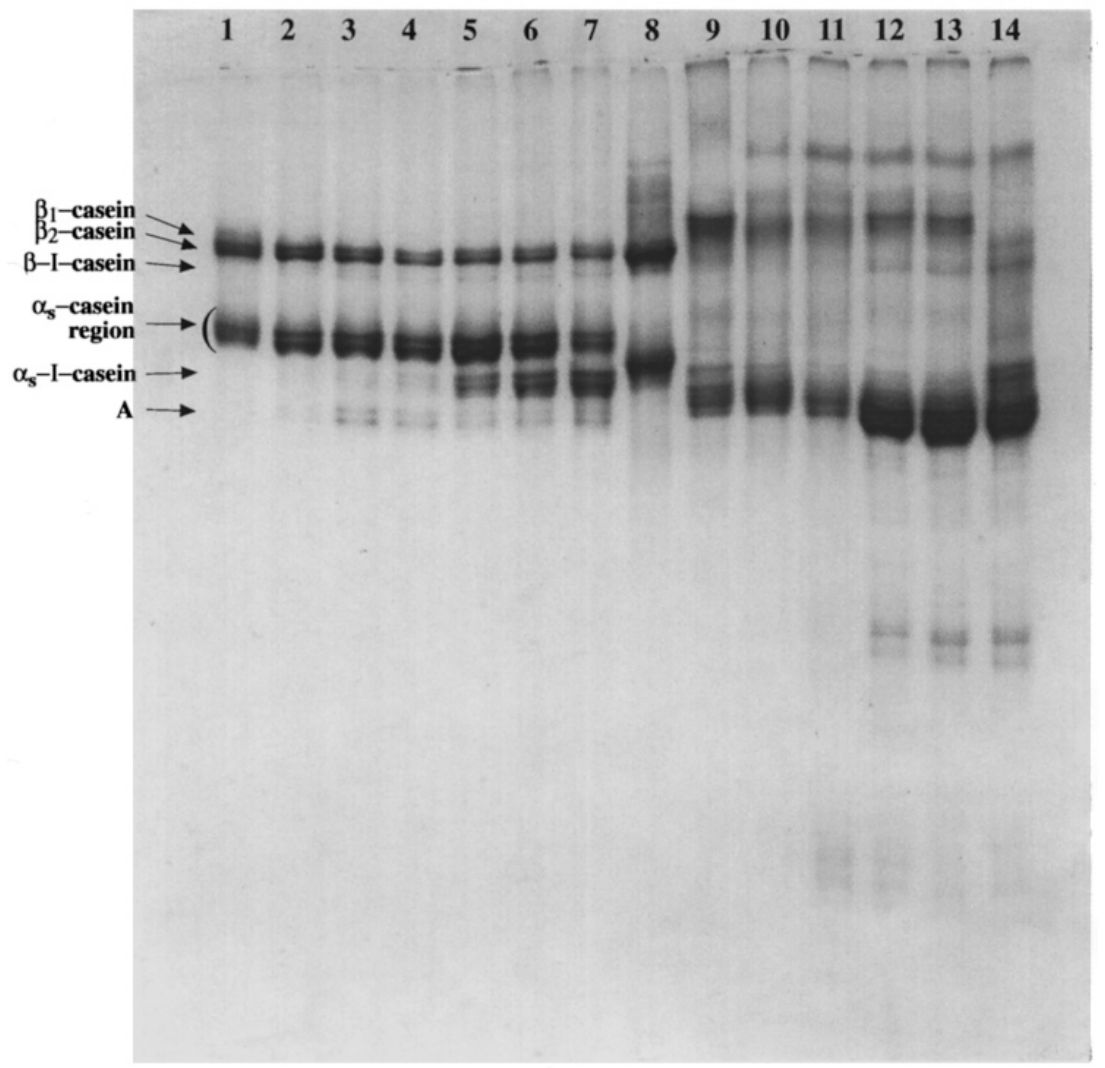

of small peptides and free amino acids that are soluble in $12 \%$ TCA. Cheeses manufactured with caprine or ovine milks exhibited higher levels of WSN/TN (which is a measure of ripening extension) than bovine cheeses, although the former showed lower levels of TCA/TN (which is a measure of ripening depth). The free amino acid index, represented by PTA-soluble N/TN (Fig. 1i), increased with ripening time in cheeses manufactured with bovine, ovine and caprine milks, but could not be considered high at any ripening time, thus suggesting that highmolecular-weight peptides were not extensively (but gradually) broken down to low-molecular-weight peptides and free amino acids by proteinases of the flowers of $C$. cardunculus, which is in agreement with previous reports $[43,44]$. Aston et al. [30] demonstrated that the amount of PTA-soluble peptides and amino acids in extracts of Cheddar cheese correlated significantly with flavour development in that cheese. The free amino acid content of the cheeses (Fig. 1j) increased during the ripening period, an observation that is probably due to bacterial proteinases or peptidases of the indigenous milk flora [42] which degrade the casein polypeptides produced by the plant rennet.

Urea-PAGE electrophoregrams of bovine water-insoluble fraction (WISF) (Fig. 2a) showed rapid degradation of $a_{\text {s1-casein }(85.9 \%)}$ with concomitant appearance and accumulation of a s1-I-casein, $i$. e. the f 24-199 fragment of a s1casein was released in a way similar to that reported for chymosin [10]. The bond in a s1-casein most susceptible to chymosin attack is Phe23-Phe24 and its hydrolysis yields a s1-I casein and a s1-(f 1-23) [45, 46]. Sousa [47] has claimed that the fragment $f$ 24-199 was the major peptide produced from pure bovine as1-casein in solution by proteinases of $\mathrm{C}$. cardunculus and this result was confirmed independently by Macedo [48]. Two other bands with higher mobility than a s1-I-casein (designated as A in Fig. 2a) were also found in cheese from the very beginning of ripening. In solution, Sousa [47] has identified bands showing similar electrophoretic mobilities; these bands could be accounted for by peptides of the form (f 24-*), which are possible fragments from hydrolysis of $a_{\text {s1 }}$-I-(f 24199) by proteinases of $C$. cardunculus. Several peptides arising from hydrolysis of a 1 -I-casein by proteinases of $\mathrm{C}$. cardunculus were identified by Macedo [48] as f 24-164, f 24-165 and f 24-166. b-casein has undergone less degra-

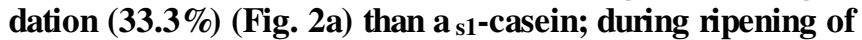
Cheddar cheese, b-casein undergoes limited hydrolysis and is apparently not hydrolysed by enzymes of animal and microbial rennets [49], although Marcos [18] and Carretero [22] have claimed the existence of breakdown products from b-casein by rennet in cheese. In bovine milk cheeses the product of such degradation process is probably b-I casein $[35,42,45]$, which is optimally released from bcasein by rennet at pH 6.4. The bonds in bovine b-casein most susceptible to chymosin and to proteinases from extracts of C. cardunculus are Leu192-Tyr193 and Ala189-Phe190 [47, 48] and either of them yields b-I- 
Fig. 2c Urea-PAGE electrophoregrams $(12.5 \% \mathrm{~T}, 4 \% \mathrm{C}$; pH 8.9) of the water-insoluble fraction (WSF) (lanes 2-7) and the water-soluble fraction (WSF) (lanes 9-14) for bovine (a), ovine (b) and caprine (c) cheeses manufactured with extracts of $\mathrm{C}$ cardunculus after $0,7,14,28,42$ and 68 days of ripening, respectively. Bovine Na-caseinate (a, lanes 1 and 8 ; $b$ and $c$, lane 8 ), ovine Na-caseinate (b, lane 1), and caprine Na-caseinate (c, lane 1) are also included

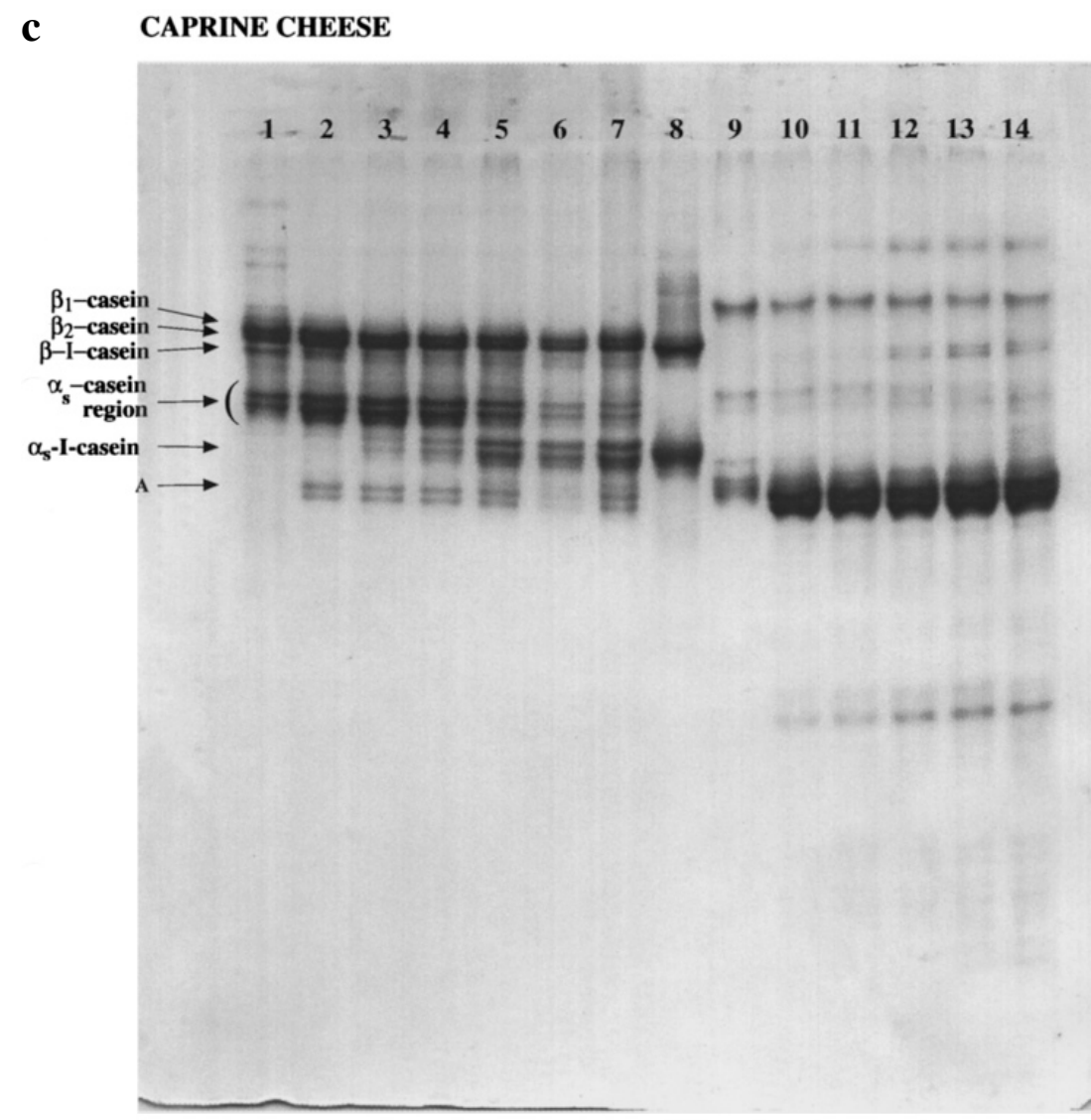

casein [47] upon enzymatic attack. Several bands with low electrophoretic mobility (Fig. 2a) are accounted for by gcaseins, i.e. b-casein fragments arising from degradation of b-casein by plasmin [50] or from similar attack by the enzymes present in the plant coagulant utilized [37, 51]. Plasmin cleaves peptide bonds of $b$-casein, thus producing three large C-terminal fragments of low electrophoretic mobility, i.e. $g_{1}-, g_{2}$ - and $g_{3}$-caseins [46], which have been previously identified in Cheddar cheese [45]; in our assays these bands increased gradually in darkness throughout maturation. Urea-PAGE electrophoregrams of WISF of ovine and caprine milk cheeses (Fig. 2b, c) showed a group with lower mobility, which is likely accounted for by b-casein (i.e., the set of $b_{1}$ - and $b_{2}$-caseins considered together) and was degraded by proteinases of $\mathrm{C}$. cardunculus to approximately the same extent $(33.1 \%)$ as bovine bcasein, but which in caprine milk cheeses was degraded to a higher extent $(\mathbf{4 3 . 5 \% )}$ ) than bovine b-casein. Ovine casein hydrolysed by calf chymosin at $\mathrm{pH} 6.5,5.5$ and 5.2 in the presence of $5 \% \mathrm{NaCl}$ showed a pair of bands of higher electrophoretic mobility than b-casein and comparable to bovine b-I-casein; cleavage sites in ovine b-casein by chymosin were Leu190-Tyr191 and Ala187-Phe188 [53]. Trujillo et al. [54] found that b-I-casein was produced at all pH values and increased as $\mathrm{pH}$ was increased; at low pH values $(\mathrm{pH} \leq 4.6)$ the polypeptide $b$-II-casein was the main breakdown product observed and b-III-casein was not virtually detected at any $\mathrm{pH}$ values in the presence of $5 \%$
$\mathrm{NaCl}$. Bovine, ovine and caprine b-caseins have relatively similar amino acid sequences (about $90 \%$ homology), and the most significant difference in caprine b-casein arises from deletion of the Pro179-Tyr180 vector [53], thus suggesting that caprine b-casein could be attacked by calf rennet in the same regions described to be susceptible to cleavage by chymosin in bovine b-casein. The three bands with highest mobility in lanes 1 of Fig. 2b, c, i.e. those designated as a $a_{\mathrm{s}}$-casein region, showed degradation levels of $47.0 \%$ and $86.5 \%$ in ovine and caprine milk cheeses, respectively. Bands with greater electrophoretic mobility than as-caseins appeared and became more intense as ripening elapsed; two or three such bands were apparent by 28 or by 7 days of ripening in ovine and caprine milk cheeses, respectively. Ovine a s-casein was hydrolysed by calf chymosin to a set of bands of higher electrophoretic mobility which may correspond to bovine $a_{\text {s1 }}$-I-casein. The most susceptible bond in ovine a $a_{\mathrm{s}}$-casein was Phe23-Val24 [53]; therefore, the electrophoretic band designated as a $\mathbf{s}_{\mathrm{s}}-$ I-casein in Fig. 2b is probably the peptide Val24-Trp199. Two bands (see Fig. 2a) with greater electrophoretic mobility than the $a_{\mathrm{s}}$-caseins, and tentatively termed $\mathrm{A}$, were produced from the very beginning of ripening and became more intense as ripening time elapsed; these bands are not present if cheese is manufactured with calf rennet [55]. Similar electrophoretic bands were reported in cheese manufactured with extracts from flowers of Cynara spp. $[37,51]$ and in solutions of bovine $a_{s 1}$-casein when incu- 
bated with extracts of $C$. cardunculus [47]. Urea-PAGE electrophoregrams of bovine, ovine and caprine watersoluble fraction (WSF) (Fig. 2a-c) showed increasing numbers of small bands throughout ripening, an observation that is consistent with the variation of the WSN/TN index (Fig. 1g).

In view of the overall physicochemical and biochemical data generated, one can conclude that primary proteolysis (measured by the amount of soluble nitrogen compounds) is higher in ovine and caprine milk cheeses than in bovine milk cheeses manufactured with aqueous extracts of flowers of $C$. cardunculus and that all types of cheese showed similar levels of TCA-soluble N/TN and PTA-soluble N/ TN. Urea-PAGE analyses of the WISF of cheeses manufactured with aqueous extracts of flowers of $\mathrm{C}$. cardunculus have shown more extensive proteolysis of $a_{\text {s1-casein in }}$ bovine milk cheese and the $a_{\mathrm{s}}$-casein region in caprine milk cheese than of the a s-casein region in ovine milk cheese, and less extensive proteolysis of $b$-casein than a s-casein in all types of cheese. The water-soluble extract showed increasing numbers of electrophoretic bands throughout ripening, an observation that is consistent with the increase of the WSN/TN ratio.

Acknowledgements Financial support for author M. J. Sousa was provided by a PhD fellowship issued by program PRAXIS XXI (BD2763/93). Partial funding for this research work was provided through grants within program AAIR [project Design and production of an enzymatic and microbial mixture to improve the process ewe's cheese (Spain, France, Italy and Portugal) safety and quality and to get a novel functional food as a response to European demand for new products low in cholesterol and protein enriched] and Agência de Inovação (project MAQUETTE: MelhorAmento de QUEijos Tradicionais e sua TEcnologia). The authors are deeply indebted to the members of Estação Experimental de Lacticínios (Paços de Ferreira) for their cooperation in the experimental manufacture and ripening of cheeses under the auspices of Direccção Regional de Agricultura de Entre Douro e Minho (Portugal).

\section{References}

1. Rank TC, Grappin R, Olson NF (1985) J Dairy Sci 68: 801-805

2. Fox PF (1989) J Dairy Sci 72: 1379-1400

3. Desmazeaud MJ, Gripon JC (1977) Milchwissenschaft 32: $731-734$

4. Green ML (1977) J Dairy Res 44: 159-188

5. Lawrence RC, Heap HA, Gilles J (1984) J Dairy Sci 67: $1632-1645$

6. Lawrence RC, Creamer JK, Gilles J (1987) J Dairy Sci 70: $1748-1760$

7. Visser FMW, de Groot-Mostert AEA (1977) Neth Milk Dairy J 31: 247-264

8. Kuchroo CN, Fox PF (1982) Milchwissenschaft 37: 331-335

9. Reville WJ, Fox PF (1978) Ir J Food Sci Technol 2: 67-76

10. McSweeney PLH, Pochet S, Fox PF, Heally A (1994) J Dairy Res 61: 587-590

11. Aston JW, Durward IG, Dulley JR (1983) Aust J Dairy Technol 38: 55-59

12. O'Keeffe RB, Fox PF, Daly C (1976) J Dairy Res 43: 97-107

13. Yvon M, Chabanet C, Pélissier JP (1989) Int J Peptide Protein Res 34: 166-176

14. Venema DP, Herstel H, Elenbaas HL (1987) Neth Milk Dairy J 41: 215-226

15. O'Keeffe AM, Fox PF, Daly C (1978) J Dairy Res 45: 465-477
16. Creamer LK (1991) Bulletin 261: 14-28 IDF Brussels

17. Creamer LK (1979) Degradation of casein components during cheese maturation In: Chiba H, Fujimaki M, Iwai K, Mitsuda H, Morita Y (eds) Proceedings of the Fifth Intemational Congress of Food Science and Technology. Elsevier, New York, pp 340-346

18. Marcos A, Esteban MA, León F, Femández-Salguero J (1979) J Dairy Sci 62: 892-900

19. Richardson BC, Creamer LK (1974) Biochim Biophys Acta 365: 133-137

20. Richardson BC, Creamer LK (1976) N Z J Dairy Sci Technol 11: $46-53$

21. Richardson BC, Creamer LK (1975) Biochim Biophys Acta 393: $37-47$

22. Carretero C, Trujillo AJ, Mor-Mur M, Pla R, Guamis B (1994) J Agric Food Chem 421: 456-1550

23. Boulanger A, Grosclaude F, Mahé MF (1984) Gent Sel Evol 16: 157-176

24. Grappin R, Jeunet R, Pillet R, Le Toquin AI (1981) Lait 61: $117-133$

25. Grosclaude F, Mahé MF, Brignon G, Di Stasio L, Jeunet L (1987) Gent Sel Evol 19: 399-412

26. Quilles AJ, Gonzalo C, Fuentes F, Hevia M, Sanchez JM (1991) Anim Prod 52: 311 -316

27. Macedo A, Malcata FX, Oliveira JC (1993) J Dairy Sci 76: 1725-1739

28. Kosikowski FV (1982) Analysis. In: Kosikowski FV et al. (eds) Cheese and fermented milk foods, 2nd edn. Brooktondale, New York, pp 560-576

29. Furtado MM, Partridge JA (1988) J Dairy Sci 71: 2877-2885

30. Aston JW, Creamer LK (1986) N Z J Dairy Sci Technol 21: $229-248$

31. Folkertsma B, Fox PF (1992) J Dairy Res 59: 217-224

32. Andrews AT (1983) J Dairy Res 50: 45-55

33. Shalabi SI, Fox PF (1987) Ir J Food Sci Technol 11: 135-151

34. Blakesley RW, Boezi JA (1977) Anal Biochem 82: 55-581

35. Noomen A (1978) Neth Milk Dairy J 32: 49-68

36. Noomen A (1983) Neth Milk Dairy J 37: 229-232

37. Femández del Pozo B, Gaya P, Medina M, Rodriguez-Martín A, Nuñez M (1988) J Dairy Res 55: 457-464

38. Poulet B, Huertas M, Sánchez A, Cáceres P, Lamiba G (1991) J Dairy Res 58: 231-238

39. Mulvihill DM, Fox PF (1980) Ir J Food Sci Technol 4: 13-23

40. Fontecha J, Peláez C, Juarez M (1994) Z Lebensm Unters Forsch 198: 24-28

41. Visser FMW (1977) Neth Milk Dairy J 31: 210-239

42. Gripon JC, Desmazeaud MJ, Le Bars D, Bergére JL (1975) Lait 55: 502-513

43. Heimgartner U, Pietrzak M, Geertsen R, Brodelius P, da Silva Figueiredo AC, Pais MSS (1990) Phytochemistry 29: 1405-1410

44. Nuñez M, Femandez del Pozo B, Rodriguez-Martin MA, Gaya P, Medina M (1991) J Dairy Res 58: 511-519

45. McSweeney PLH, Olson NF, Fox PF, Heally A, Hojrup P (1994) J Dairy Res 60: 401-412

46. Visser S (1981) Neth Milk Dairy J 35: 65-88

47. Sousa MJCF (1993) Plant rennet substitute from flowers of Cynara cardunculus. MSc Thesis, National University of Ireland Cork

48. Macedo I (1993) Especificidade caseinolítica da protease de Cynara cardunculus $\mathrm{L}$. PhD Thesis, Universidade de Coimbra Portugal

49. Phelan JA, Guirey I, Fox PF (1973) J Dairy Res 40: 105-112

50. Fox PF, Singh TK, McSweeney PLH (1997) Proteolysis in cheese during ripening. In: Varley $J$ (ed) Advances in biochemistry of milk products. Royal Society of Chemistry, London (in press)

51. Serrano E, Marcos A (1980) Arch Zootec 29: 11-22

52. Whyte NH (1995) M Sc Thesis National University of Ireland, Cork

53. Addeo F, Mauricello R, Di Luccia A (1988) J Dairy Res 55: $413-421$

54. Trujillo AJ, Guamis B, Carretero C (1995) J Agric Food Chem 43: 1472-1478

55. Sousa MJ, Malcata FX (1997) J Agric Food Chem 45: 78-81 